\title{
A Problemática dos Refugiados na América Latina e no Brasil
}

\author{
Julia Bertino Moreira *
}

Resumo: 0 presente artigo objetiva analisar como os países da América Latina têm tratado a problemática dos refugiados desde o pós-guerra até os dias atuais. A região, logo após a Segunda Guerra Mundial, recebeu grande contingente de refugiados provenientes da Europa. Entretanto, durante os anos 1970 e 1980, vários de seus países (como El Salvador, Nicarágua, Guatemala e Chile) foram governados por regimes ditatoriais, o que gerou grande fluxo de refugiados latino-americanos no mundo. Tendo esse objetivo em vista, estudaram-se os principais instrumentos internacionais e regionais relativos aos refugiados (a Convenção Relativa ao Estatuto dos Refugiados de 1951, o Protocolo sobre o Estatuto dos Refugiados de 1967 e a Declaração de Cartagena de 1984), destacando os contextos em que foram elaborados, assim como se apontaram os países da região que ratificaram estes instrumentos.

Palavras-chave: Refugiados, Políticas Imigratórias, Conflitos, Direito Internacional dos Refugiados, Direitos Humanos.

Abstract: This article aims to analyze how Latin American States have been dealing with the refugees' issue since the post-war. The region, soon after the World War II, received a large contingent of refugees. However, during the 1970's and 1980's, several of these States (such as El Salvador, Nicaragua, Guatemala and Chile) were governed by dictatorial regimes, which generated a great flux of Latin American refugees around the world. Considering this objective, this article studies the principal international and regional instruments relative to refugees (the 1951 Convention Relating to the Status of Refugees, the 1967 Protocol Relating to the Status of Refugees and the 1984 Cartagena Declaration), focusing the context of their elaboration, and also points out the Latin American States which signed these instruments.

Keywords: Refugees, Immigratory Politics, Conflicts, International Refugee Law, Human Rights

\footnotetext{
* Graduada em Direito pela PUC/SP, Mestranda em Relações Internacionais do Programa San Tiago Dantas (UNESPUNICAMP-PUC/SP). E-mail: juliabertinobr@yahoo.com.br. Recebido em 07/11/05 e aceito em 15/12/2005.
} 


\section{Introdução}

Inicialmente, vale destacar que a problemática dos refugiados está intrinsecamente relacionada com a ocorrência de guerras civis no plano internacional, que assumem motivos variados, como religioso, étnico, político ou econômico. Isso porque esses conflitos causam graves violaçóes aos direitos humanos da população civil atingida, à medida que atentam contra a sua vida (incluindo a integridade física), liberdade e segurança. Além disso, as situaçóes de conflito colocam em risco grupos ou indivíduos que apresentem etnias ou religiōes minoritárias no país ou opinióes políticas diversas do governo, estando sujeitos, assim, a sofrer ameaças ou efetivas perseguiçóes. Em razão disso, são impulsionados a deixar forçosamente seus países de origem para procurar refúgio em outros Estados.

O reflexo desse movimento de deslocamento forçado é uma população mundial atual de, aproximadamente, 9,7 milhóes de refugiados (ACNUR, 2004b, p. 3). Deste total, 38.300 são provenientes da América Latina e do Caribe (ACNUR, 2004b, p. 4). É de se ressaltar que o crescente contingente de refugiados espalhados pelo globo representa uma problemática que desafia a comunidade internacional há mais de cinqüenta anos.

Diante disso, três soluçôes são implementadas para resolver a problemática dos refugiados: a repatriação voluntária, a integração local e o reassentamento. Através da primeira, o indivíduo é mandado de volta ao seu país; por meio da segunda, é acolhido pelo país no qual ingressou, obtendo refúgio; e, pela terceira, é enviado a um terceiro país.

A repatriação voluntária vislumbra-se como a mais difícil solução, ao mesmo tempo em que é a mais desejada e, por esse segundo motivo, é muito incentivada pelo ACNUR, juntamente com os Estados de origem e de refúgio. Isso porque o sentimento natural do ser humano é retornar ao seu lar, onde encontra suas origens e nele se identifica. Entretanto, ante as perseguiçôes e violaçóes de seus direitos, que o levaram a deixar seu Estado de origem, entende-se assaz complicado esse retorno, principalmente se essas razóes ainda subsistirem (ANDRADE, 1996a, p. 40).

Ao seu turno, a integração local garante ao refugiado condiçóes de reestruturar sua vida, estabelecendo-se num Estado diverso daquele de sua origem, razão pela qual o ACNUR auxilia esse país que o acolheu no sentido de promover sua inserção na comunidade local. Porém, esta solução 
também acarreta algumas dificuldades no tocante à adaptação do refugiado à nova sociedade na qual será inserido, uma vez que esta pode representar uma cultura (hábitos, crenças e tradiçóes) diversa daquela de sua origem (ANDRADE, 1996a, p. 40-41).

Por fim, o reassentamento trata-se da inserção do refugiado em um terceiro Estado, em decorrência de dificuldades (como os casos em que a integridade física do refugiado se apresenta em perigo) quanto à sua integração naquele país que o recebeu (ANDRADE, 1996a, p. 41).

Traçadas essas consideraçóes iniciais, analisaremos a seguir o contexto em que se configurou a problemática dos refugiados, bem como os instrumentos elaborados com o intuito de regulamentá-la.

\section{Os instrumentos de proteção aos refugiados}

\section{A Convenção relativa ao estatuto de refugiado de 1951}

A Segunda Guerra Mundial (1939-1945) apresentou-se como um importante marco histórico com relação à problemática dos refugiados. Em primeiro lugar, porque foram verificadas as maiores atrocidades já praticadas contra o ser humano, em razão do holocausto, ocasionando uma preocupação internacional com a dignidade da pessoa humana (PIOVESAN, 2004, p. 131-132). Em segundo lugar, porque foram gerados os maiores deslocamentos humanos observados na História do mundo moderno, perfazendo-se mais de 40 milhóes de pessoas deslocadas provenientes da Europa, além de, aproximadamente, 13 milhóes de pessoas de origem alemã que foram expulsas de países como Polônia, Checoslováquia e daqueles que formavam a União das Repúblicas Socialistas Soviéticas (URSS), e, ainda, 11,3 milhóes de trabalhadores forçados e pessoas deslocadas na Alemanha (ACNUR, 2000, p. 13).

Essa situação caótica que se constatava no continente europeu, completamente devastado pela guerra, causou grande preocupação à comunidade internacional, principalmente aos países aliados (Reino Unido, França, URSS e EUA) (ACNUR, 2000, p. 13). Cabe destacar que os países da América Latina se inseriram nesse contexto internacional, haja vista que, durante o pós-guerra, nos anos de 1947 a 1952, acolheram $100 \mathrm{mil}$ refugiados europeus em seus territórios (ZARJEVSKI, 1987, p. 211). 
Diante disso, em dezembro de 1949, a Organização das Naçóes Unidas (ONU), mediante deliberação na Assembléia Geral, decidiu criar um órgão específico para tratar da questão dos refugiados: o Alto Comissariado das Nações Unidas para os Refugiados (ACNUR), que iniciaria seus trabalhos em $1^{\circ}$ de janeiro de 1951 (ACNUR, 2000, p. 19). Em 28 de julho do mesmo ano, esta Organização elaborou o primeiro instrumento de proteção internacional aos refugiados: a Convenção Relativa ao Estatuto dos Refugiados, que entrou em vigor no dia 21 de abril de 1954 (ACNUR, 1996, p. 3).

Além disso, no mesmo ano, foi criado o Comitê Consultivo para Refugiados, estabelecido pelo Conselho Econômico e Social da ONU. Este escolheu quinze Estados (incluindo membros e não-membros da Organização), dentre eles o Brasil e a Venezuela, que haviam recebido grande contingente de refugiados gerados pela a Segunda Guerra Mundial para fazerem parte do Comitê Consultivo. De fato, o Brasil foi o país da América Latina que acolheu o maior número de refugiados provenientes da Europa, logo após a guerra, totalizando 40 mil pessoas em 1954. Ao seu turno, a Venezuela havia recebido 18 mil refugiados no mesmo ano (ZARJEVSKI, 1987, p. 211). Ademais, segundo o ACNUR, essa escolha teve como critério países que demonstraram interesse e devoção para solucionar a problemática dos refugiados (ACNUR, 2001).

Outrossim, em 1957, a Assembléia Geral da ONU decidiu criar o Comitê Executivo do ACNUR, que foi estabelecido pelo Conselho Econômico e Social em 1958, iniciando suas atividades em 1959 (ACNUR, 2001). Vale registrar que o Comitê Executivo é composto por representantes de países que têm demonstrado maior grau de compromisso com a problemática dos refugiados, e que aprovam, anualmente, os programas do ACNUR e suas diretrizes em matéria de proteção aos refugiados (ACNUR, 2003). Dentre seus membros, encontram-se Argentina, Brasil, Chile, Colômbia, Equador, México, Nicarágua e Venezuela (ACNUR, 2001).

\section{A definição clássica de refugiado}

No que diz respeito à Convenção, uma de suas maiores contribuiçóes foi definir o que se entenderia por "refugiado", estabelecendo o que ficou conhecido por "definição clássica de refugiado" (ANDRADE, 1997a). Segundo a redação do primeiro dispositivo deste instrumento, o termo se aplica a qualquer pessoa: 
Que, em conseqüência de acontecimentos ocorridos antes de 1 de Janeiro de 1951, e receando com razão ser perseguida em virtude da sua raça, religião, nacionalidade, filiação em certo grupo social ou das suas opinióes políticas, se encontre fora do país de que tem a nacionalidade e não possa ou, em virtude daquele receio, náo queira pedir a proteção daquele país; ou que, se não tiver nacionalidade e estiver fora do país no qual tinha a sua residência habitual após aqueles acontecimentos, não possa ou, em virtude do dito receio, a ele não queira voltar (ACNUR, 1996, p. 61).

De acordo com o texto da Convenção, os termos "acontecimentos ocorridos antes de $1^{\circ}$ de janeiro de 1951" poderiam ser entendidos de duas maneiras: em primeiro lugar, como aqueles que tiveram lugar na Europa (o que foi interpretado como uma "reserva geográfica", reconhecendo-se como refugiados apenas pessoas de origem européia, nos dizeres de ANDRADE, 1997b, p. 161); e, em segundo lugar, como aqueles que tiveram lugar na Europa ou fora desta. Tendo isso em vista, a Convenção previa que caberia ao Estado-parte adotar uma dessas fórmulas, mediante declaração feita quando da assinatura, adesão ou ratificação do instrumento. Ademais, a qualquer momento, o Estado que tivesse adotado a primeira fórmula (mais restritiva) poderia, mediante comunicação ao Secretário-Geral da ONU, adotar a segunda delas, que abarcava um grupo maior de pessoas na definição de refugiado (ACNUR, 1996, p. 62).

\section{A ratificação da Convenção pelos países latino-americanos}

Todos os países da América Latina assinaram a Convenção de 1951, com exceção de Cuba e México (ACNUR, 1996, p. 91; ANDRADE, 1998, p. 403).

\section{O Protocolo sobre o Estatuto de Refugiado de 1967}

Ademais, em 1967, tendo em vista novos acontecimentos ocorridos no cenário internacional, como a descolonização africana, gerando novo fluxo de refugiados, foi elaborado o Protocolo sobre o Estatuto dos Refugiados.

Este buscou pôr fim à chamada "reserva temporal" da Convenção, a qual estabelecia que só seriam reconhecidos como refugiados aqueles que tinham receio de serem perseguidos "em conseqüência dos acontecimentos 
ocorridos antes de $1^{\circ}$ de janeiro de 1951", passando-se a não mais se aplicar esses termos à definição de refugiado (ACNUR, 1996, p. 85; ANDRADE, 1996b, p. 8).

\section{A ratificação do Protocolo pelos países latino-americanos}

Todos os países da América Latina aderiram ao Protocolo de 1967, com exceção de Cuba e México (ACNUR, 1996, p. 91; ANDRADE, 1998, p. 403).

\section{A Declaração de Cartagena de 1984}

Nos anos 1970 e 1980, vários países da América Latina (destacando-se El Salvador, Nicarágua, Guatemala e Chile) tiveram, em seus governos, regimes ditatoriais e foram palco de graves conflitos armados por motivos políticos, o que provocou um fluxo de mais de 2 milhóes de refugiados provenientes apenas dos países da América Central (ANDRADE, 1998, p. 400).

A Nicarágua foi governada pelo regime Somoza, que teve o apoio dos Estados Unidos, por três décadas. Nos anos 1970, o povo se voltou contra o ditador Anastasio Somoza Dabayle, impulsionando-o a fugir do país em 1979, quando, então, os sandinistas (que constituíam a Frente Sandinista de Libertação Nacional) passaram a exercer o poder na Nicarágua. Com isso, muitas pessoas, relacionadas ao governo Somoza, deixaram o país, enquanto outras, que o haviam abandonado por causa do regime ditatorial, retornavam (ACNUR, 2000, p. 128).

Diante dessa situação, em 1978, aproximadamente 15 mil nicaragüenses obtiveram residência temporária em Honduras (ZARJEVSKI, 1987, p. 216), sendo que, em 1981, o número de refugiados neste país atingiu 30 mil pessoas (ACNUR, 2000, p. 133). Vale destacar ainda que, durante a guerra civil ocorrida na Nicarágua, 100 mil pessoas oriundas deste país conseguiram asilo temporário na Costa Rica (ZARJEVSKI, 1987, p. 219).

Por sua vez, El Salvador foi alvo de golpes políticos desde sua independência, o que gerou a formação de grupos rebeldes a partir dos anos 1970. Os camponeses também passaram a aderir a organizaçôes que pregavam a reforma agrária e justiça social, sofrendo grande repressão por parte do governo. Eis que, em 1981, os grupos da oposição se uniram para formar a Frente Farabundo Marti para a Libertação Nacional (FMLN), ganhando grande força política tanto em nível nacional como internacional. 
Os Estados Unidos, na tentativa de barrar essa expansão, aumentaram a ajuda militar fornecida ao governo salvadorenho, ensejando um conflito entre este e a FMLN, que perdurou pela década de 1980 (ACNUR, 2000, p. 128-129).

Em decorrência do conflito, a partir desta década, salvadorenhos passaram a procurar abrigo nos seguintes países: Honduras (ACNUR, 2000, p. 133), somando 18 mil refugiados em 1982; Costa Rica, perfazendo-se 10 mil refugiados no mesmo ano; Nicarágua; Estados Unidos; e Belize (ZARJEVSKI, 1987 , p. 217-221). Vale mencionar que, ao final dos anos 1980, o México era o país que acolhia o maior número de refugiados salvadorenhos, totalizando 120 mil pessoas (ACNUR, 2000, p. 223).

Ademais, a Guatemala viveu processo semelhante àquele verificado em El Salvador, visto que os grupos rebeldes se insurgiram contra o regime militar na mesma época. Em represália, este iniciou, em 1981, uma campanha de 18 meses contra os guerrilheiros e a população indígena, causando a morte de dezenas de milhares de guatemaltecos, bem como o deslocamento interno de 1 milhão de pessoas. Após isso, os grupos rebeldes formaram a Unidade Revolucionária Nacional Guatemalteca (URNG), propiciando a ocorrência de novos conflitos com o governo guatemalteco (ACNUR, 2000, p. 131132).

Estes conflitos na Guatemala geraram, por conseguinte, outro fluxo de refugiados, que se dirigiu para o México, em 1981 (ACNUR, 2000, p. 135), atingindo 30 mil pessoas em 1982; algumas centenas deles, para a Nicarágua; e pequenos grupos, para a Costa Rica e para o Panamá (ZARJEVSKI, 1987, p. 216-223).

Por fim, em 1973, o Chile vivenciou um golpe político que ensejou a queda do governo Allende e a tomada do poder pelos militares. Em face disso, muitos refugiados políticos que haviam sido ali acolhidos, temendo ser deportados aos seus países de origem, procuraram asilo em igrejas e embaixadas (ZARJEVSKI, 1987, p. 212). Ao mesmo tempo, os chilenos começaram a deixar o país, tendo sido acolhidos na Argentina, totalizando 4 mil pessoas reassentadas, enquanto 2 mil tiveram permissão para residir e trabalhar no país; e no Peru, onde 3 mil pessoas obtiveram estadia temporária (ZARJEVSKI, 1987, p. 213-214). Vale registrar que, na segunda metade dos anos 1970, muitos refugiados chilenos se instalaram no México (ZARJEVSKI, 1987, p. 223). 
Posto isso, as guerras nos países da América Central deram origem a mais de 2 milhóes de refugiados, que fugiram para países da mesma região, como já visto, e para países da América do Norte (EUA e Canadá). Do total de 500 mil pessoas que foram para os Estados Unidos, a maioria não foi reconhecida como refugiada, sendo que muitos nem tiveram a oportunidade de solicitar refúgio, por razóes políticas. Nos países da América Central e no México, foram reconhecidos 150 mil refugiados (ACNUR, 2000, p. 132).

Diante desse contexto, em 1984, foi elaborada a Declaração de Cartagena, um instrumento regional de proteção aos refugiados, aplicável ao sistema interamericano. Com a Declaração, pretendia-se alterar a definição de refugiado dada pela Convenção, haja vista que esta não abarcava as situaçóes de conflitos armados, praticados sistematicamente na região durante as décadas de 1970 e 1980.

\section{A definição ampliada de refugiado}

A Declaração passou a incluir na definição de refugiado pessoas que deixaram seus países porque sua vida, segurança ou liberdade foram ameaçadas em decorrência da violência generalizada, agressão estrangeira, conflitos internos, violação massiva dos direitos humanos ou outras circunstâncias que perturbaram gravemente a ordem pública (DECLARAÇÃO, 2001, 425-426). Assim, por ter estendido o alcance do termo "refugiado", este instrumento regional trouxe, em seu bojo, o que ficou conhecido por "definição ampliada de refugiado" (ANDRADE, 1997b, p. 162).

\section{A aplicação da Declaração pelos países latino-americanos}

Ainda que a Declaração de Cartagena não possua caráter vinculativo, obrigando os Estados a cumpri-la, a maioria dos países da América Latina, mesmo aqueles que não a assinaram, vêm aplicando a definição ampliada de refugiado contida nesse instrumento aos pedidos de refúgio que lhes são submetidos (ACNUR, 2000, p. 123). Nesse sentido, "a Declaração se tornou um direito costumeiro, por ter sido invocada sistematicamente pelos países latino-americanos" (ANDRADE, 1998, p. 402).

Ademais, muitos destes países adotaram a referida definição de refugiado em suas legislaçóes domésticas, como foram os casos da Argentina, Belize, 
Brasil, Bolívia, Equador, El Salvador, Guatemala, Honduras, México, Paraguai e Peru (ACNUR, 2004a).

\section{O posicionamento do Brasil com relação à problemática dos refugiados}

O Brasil ocupa destaque na América do Sul por ter sido o pioneiro a regulamentar a proteção aos refugiados (ACNUR, 2003). Isso porque, no âmbito internacional, foi o primeiro país da região a aprovar a Convenção de 1951, o que se deu em 1960, aderiu ao Protocolo de 1967 em 1972 (COMISSÃO JUSTIÇA E PAZ, 1994, p. 46); e, no âmbito nacional, também foi o primeiro a elaborar uma lei específica sobre refugiados (a Lei Federal no 9.474/97), em 1997. E, embora não tenha assinado a Declaração de Cartagena de 1984, passou a aplicar a definição ampliada de refugiado contida nesse instrumento desde 1989 (ALMEIDA, 2001, p. 148).

No tocante ao posicionamento brasileiro em relação aos refugiados que chegavam ao território nacional em busca de refúgio, vale lembrar que o país, quando aderiu à Convenção, estabeleceu a "reserva geográfica", através da qual só reconhecia como refugiados pessoas de origem européia. Em razão disso, no decorrer das décadas de 1970 e 1980, em que se verificou grande fluxo de refugiados provenientes da América Latina, como o Brasil mantinha a reserva, não podia acolher latino-americanos em seu território, concedendolhes apenas o "visto de turista", que permitia a estadia provisória de noventa dias no país (ALMEIDA, 2001, p. 119). Durante esse período, essas pessoas aguardavam para serem reassentadas em um terceiro país (ANDRADE, 1996b, p. 9-10; ALMEIDA, 2001, p. 119).

A decisão de manter a referida reserva e de conceder estadia provisória aos não-europeus foi fruto de um acordo entre o governo brasileiro e o ACNUR, que iniciou sua missão no Brasil em 1977 (ALMEIDA, 2001, p. 115). No final dos anos 70 e início dos $80^{1}$, foi instalado um Escritório do ACNUR no Rio de Janeiro, que teve como função reassentar cerca de $20 \mathrm{mil}$ sul-americanos (dentre eles, argentinos, uruguaios, chilenos e paraguaios)

\footnotetext{
${ }^{1}$ Vale destacar que há divergência com relação a essa data em duas obras pesquisadas, tendo em vista que uma, Direitos Humanos e Não Violência (p. 119) de Guilherme Assis de Almeida, menciona que o escritório do ACNUR foi estabelecido no Rio de Janeiro em janeiro de 1978, enquanto a outra, Direitos Humanos no Brasil: $1992-1993$ (p. 47) da Comissão Justiça e Paz - Arquidiocese de Brasília, em 1982.
} 
(ALMEIDA, 2001, p. 119) em outros países (COMISSÃO JUSTIÇA E PAZ, 1994, p. 47), principalmente da Europa, Estados Unidos, Canadá, Austrália e Nova Zelândia (ALMEIDA, 2001, p. 115).

Com o início da década de 1980, ocorreram algumas mudanças significativas no posicionamento brasileiro em relação à acolhida de refugiados não-europeus. Em 1979, 150 vietnamitas foram abrigados em nosso território e, embora o governo não lhes tenha reconhecido a condição de refugiados, concedeu-lhes visto temporário de estadia, o que legalizava sua situação jurídica e permitia que trabalhassem legalmente no país; além disso, dezenas de cubanos foram recebidos pelo país, tendo sido assistidos pela Comissão de Justiça e Paz, em São Paulo (ALMEIDA, 2001, p. 120). A partir de 1984, permitiu-se a estadia de refugiados no território nacional por período não limitado, enquanto se aguardava o reassentamento em outros países (ANDRADE, 1996b, p. 9).

No entanto, é a partir de meados da década de 1980, quando se desenrola o processo de democratização não só do Brasil, como de outros países da América do Sul, que se verifica um avanço quanto ao tratamento da problemática dos refugiados pelo governo brasileiro.

Diante desse contexto, em 1986, com o auxílio do ACNUR, 50 famílias de fé Bahái, provenientes do Irã, foram acolhidas pelo Brasil, pela aplicação do estatuto de asilados, haja vista que, em razão da "reserva geográfica" sustentada pelo país, não lhes poderia ser reconhecida a condição jurídica de refugiados (ALMEIDA, 2001, p. 122). Vale salientar que essa decisão do governo brasileiro representou uma inovação jurídica, revelando o comprometimento do país com a questão dos refugiados. Em 19 de dezembro de 1989 (ANDRADE, 1996b, p. 10; ALMEIDA, 2001, p. 124), o Brasil finalmente veio a revogar a "reserva geográfica", por meio do Decreto no 98.602/89 (ALMEIDA, 2001, p. 124; COMISSÃO JUSTIÇA E PAZ, 1994, p. 47).

Em face disso, embora o governo não tenha assinado a Declaração de Cartagena, passou a aplicar a definição ampliada de refugiado contida nesse instrumento desde 1989 (ALMEIDA, 2001, p. 148), quando decidiu acolher refugiados de todos os continentes do mundo.

Um exemplo fático foi verificado entre os anos de 1992 e 1994, quando, aproximadamente 1.200 angolanos chegaram no Brasil em busca de refúgio, em razão do período conturbado das eleiçóes na Angola. Nesse momento, 
as autoridades nacionais decidiram aplicar a definição ampliada de refugiado (ANDRADE, 1996b, p. 10), contida na Declaração de Cartagena (ALMEIDA, 2001, p. 126), já que os angolanos não se enquadravam na definição clássica, dada pela Convenção de 1951 (ANDRADE, 1996b, p. 10).

Por fim, vale destacar que, desde 2001, o Brasil implementa projetos de reassentamento para refugiados. O primeiro grupo recebido pelo país formava-se por afegãos. Nos dois anos seguintes, foram acolhidos mais de 105 colombianos. Ademais, em novembro de 2004, em reunião realizada na Cidade do México, para celebrar os vinte anos da Declaração de Cartagena, o Brasil resolveu estabelecer um programa regional de reassentamento de refugiados latino-americanos. O objetivo deste programa consistia em proteger os refugiados que fugiam de conflitos e perseguiçóes verificados na regiāo e, ao mesmo tempo, ajudar os países que acolhem grande contingente de colombianos, como Costa Rica e Equador (ACNUR, 2005).

\section{O contingente atual de refugiados na região}

O Brasil ainda se destaca no quadro geral de refugiados e solicitantes de refúgio da América do Sul, visto que abriga 3.193 refugiados e recebeu 566 solicitantes de refúgio em 2003. A grande maioria dos refugiados acolhidos no país provém de Angola, perfazendo 1.952 indivíduos. Por sua vez, cresce o número de latino-americanos que chega ao território brasileiro em busca de proteção, constituindo o maior grupo entre os solicitantes de refúgio, com 45 cubanos e 45 colombianos. Além disso, dentre os refugiados, existem 92 cubanos (ACNUR, 2004c, p. 90-91).

Vale registrar que também há a estatística baseada nos dados fornecidos pela Cáritas Arquidiocesana, instituição vinculada à Igreja Católica, situada em São Paulo e no Rio de Janeiro, que recebe os refugiados quando chegam ao Brasil e acompanha seu processo de integração no país. De acordo com a estatística da Cáritas, em 2003, havia 1130 refugiados acolhidos em São Paulo, dos quais 73 eram cubanos; 36, peruanos; 30, colombianos; 7, argentinos; 3, paraguaios, 2 salvadorenhos; e 1 haitiano (vide tabela 1). Portanto, é interessante notar que $13 \%$ dos refugiados que se encontravam em São Paulo naquele ano tinham origem latino-americana.

Os refugiados acolhidos no Brasil contam com o apoio de ONGs, do 
ACNUR e do governo, durante o seu processo de integração local. Eles recebem assistência, que abrange moradia (oferecida em albergues e abrigos públicos), medicamentos e assistência médica (fornecidos pelo ACNUR e por hospitais públicos), alimentaçâo (fornecida com ajuda financeira do ACNUR e através de doaçôes). Também são contemplados com proteção jurídica, sendo orientados sobre sua situação no país, e com medidas que buscam sua integraçáo na comunidade local (como aulas de português, cursos de capacitação profissional, entre outras) (ACNUR, 2002).

No que toca aos refugiados colombianos, cerca de 75 , que se encontravam no Equador e na Costa Rica, foram reassentados no Brasil em 2004, sendo instalados nas cidades de Rio Grande, São Paulo e Porto Alegre, assim como em outras localidades do sul do país. Diante disso, foram implementados programas visando à integração destes refugiados na comunidade local, que compreenderam cursos de língua portuguesa, capacitação profissional e assessoria para colocação em postos de trabalho. Além disso, o ACNUR prestou assistência aos refugiados de baixa renda e, ainda, ofereceu programas de micro-créditos para refugiados que pretendiam montar um pequeno negócio. Ressalte-se que esse projeto priorizou as mulheres colombianas em situação de risco, contemplando as que foram vítimas de violência no país de origem ou no primeiro país de acolhimento e as que se encontravam sozinhas, com filhos (ACNUR, 2005).

A partir dessa iniciativa, muitos dos refugiados colombianos conseguiram se integrar no país, contudo, outros tiveram problemas, principalmente pela dificuldade em obter trabalho. Um caso bem sucedido foi de um colombiano que, ao ingressar no Brasil, percebeu o amplo mercado gastronômico no país e decidiu fazer cursos voltados para essa área. Contando com ajuda do ACNUR, ele se tornou um dos chefs de um hotel famoso de Porto Alegre (ACNUR, 2005; ADITAL, 2005).

Nesse sentido, o fato de possuir uma profissão no país de origem pode ser um fator que facilita o processo de integração, dependendo da situação do mercado de trabalho no país de acolhimento. Como os latino-americanos têm seus diplomas reconhecidos pelo Brasil mais rapidamente do que os refugiados de outras origens (cerca de 90 dias), muitos deles conseguiram arrumar bons empregos no país. Esse foi o caso de um médico cubano, que chegou ao Brasil em 1995 e logo após o reconhecimento de seu diploma, começou a trabalhar (ISTO É, 1997). Em contrapartida, em outros casos, a alta qualificação profissional do refugiado se revelou prejudicial. Isso se 
verificou entre refugiados provenientes tanto da Colômbia quanto de Cuba e Peru, que tinham formação universitária, ocupando bons cargos em seu país de origem, mas enfrentaram o desemprego quando chegaram ao Brasil. Um exemplo disso foi o caso de um jornalista colombiano, que trabalhava na Cruz Vermelha, e não conseguiu emprego no país de acolhimento $(\mathrm{O}$ ESTADO DE SÃO PAULO, 2004).

Outra questão que pode prejudicar a integração se trata do constante estado de insegurança vivido pelos refugiados. Alguns casos foram relatados por colombianos perseguidos pelas Forças Armadas Revolucionárias Colombianas (FARC), os quais continuavam temendo por sua segurança no território brasileiro, em razão de sua proximidade com a Colômbia (DIÁRIO DE S. PAULO, 2004).

Depois do Brasil, dentre os países da América do Sul, aparece a Argentina, com 2.642 refugiados, ao passo que Bolívia, Chile, Colômbia e Peru apresentam algumas centenas de refugiados em seus territórios, e, por último, Paraguai e Venezuela, com apenas algumas dezenas deles abrigados em seus países (vide tabela 2) (ACNUR, 2004b, p. 9).

Vale salientar a situação do Equador, que, em 1999, apresentava tấosomente 310 refugiados em seu território (ACNUR, 2000, p. 309) e, em 2003, passou a acolher um enorme contingente de 6.381 pessoas, constituindo-se, atualmente, a maior população refugiada da América do Sul (ACNUR, 2004b, p. 9).

No tocante aos países das Américas Central e do Norte, a Costa Rica merece destaque por abrigar 13.508 refugiados em seu território, a maior população acolhida em toda a América Latina; seguindo-se do México, com 6.075 refugiados, e do Panamá, com 1.445 refugiados; enquanto Belize, Cuba, El Salvador, Guatemala, Honduras e Nicarágua apresentam pequenos grupos com algumas dezenas ou centenas de pessoas (vide tabela 2) (ACNUR, 2004b, p. 9).

Outrossim, com relação à origem dos refugiados latino-americanos, o maior grupo é colombiano, perfazendo 37.981 refugiados; seguindo-se pelos cubanos, que totalizam 16.103 refugiados. Os haitianos também são numerosos, constituindo 7.549 refugiados; assim como os guatemaltecos, que representam 6.696 refugiados. Além destes, outros grupos expressivos são oriundos de El Salvador e Peru, somando 5.658 e 5.582 refugiados, respectivamente (vide tabela 3) (ACNUR, 2004b, p. 21-22). 


\section{Conclusão}

Considerando o objetivo do texto, que se pautou em analisar como os países da América Latina vêm se posicionando em relação à problemática dos refugiados desde o pós-guerra até os dias atuais, é de se constatar que, no decorrer desse período, estes países foram demonstrando cooperação e comprometimento para solucionar esta difícil problemática.

Isso porque, logo após a Segunda Guerra Mundial, os países latinoamericanos acolheram um grande contingente de refugiados europeus gerados pela guerra. Diante disso, dois deles (Brasil e Venezuela) foram escolhidos para fazer parte do Comitê Consultivo do ACNUR, haja vista que haviam apresentado interesse e devoção quanto à questão dos refugiados. Vale registrar, ainda, que oito países da região são membros, hoje, do Comitê Executivo do ACNUR, composto por representantes que têm demonstrado alto compromisso com a problemática dos refugiados.

Ademais, a maioria dos países da região ratificou os principais instrumentos internacionais de proteção aos refugiados, quais sejam, a Convenção de 1951 e o Protocolo de 1967, e vêm aplicando a definição ampliada de refugiado contida no instrumento de proteção regional, qual seja, a Declaração de Cartagena. Logo, pode-se abstrair que os países latino-americanos não só se preocuparam em regulamentar a proteção aos refugiados, mas foram além: resolveram reconhecer como refugiados também aqueles que sofreram violaçóes em decorrência de conflitos armados (situação constantemente verificada na regiáo), possibilitando a acolhida de um grupo maior de refugiados, o que corrobora o comprometimento da América Latina com essa problemática.

No tocante ao fluxo de refugiados oriundo da região, vale destacar que, durante as décadas de 1970 e 1980, quando países latino-americanos foram governados por regimes ditatoriais, um enorme contingente de refugiados oriundo da América Latina abandonou seus países de origem e procurou refúgio em países vizinhos. É interessante notar que alguns destes países, como El Salvador, Guatemala e Nicarágua apresentam, hoje, algumas das maiores populaçóes de refugiados originados da região. Atualmente, observase que ainda há um elevado número de refugiados que provém da América Latina, destacando-se os colombianos e cubanos. Por outro lado, a regiáo também acolhe uma grande população de refugiados, merecendo destaque a Costa Rica e o México (que já havia abrigado muitos refugiados na década de 1980), além do Equador e Brasil. 
No tocante ao posicionamento brasileiro em relação à problemática dos refugiados, constata-se que este país foi o primeiro a regulamentar a proteção a esse grupo na América do Sul, ratificando os seus principais instrumentos internacionais de proteção. O Brasil ainda se destaca quanto ao acolhimento de refugiados em seu território: foi o país que acolheu o maior número de refugiados europeus após a Segunda Guerra Mundial e apresenta, hoje, a segunda maior população refugiada do sul da regiáo.

Contudo, o posicionamento brasileiro se apresentou contraditório em relação à problemática dos refugiados. Se, de um lado, demonstrou-se um país comprometido com esta problemática (razão pela qual foi escolhido para fazer parte do Comitê Consultivo do ACNUR e tornou-se membro do Comitê Executivo do mesmo organismo internacional), por outro lado, deixou de acolher grande contingente de refugiados latino-americanos durante as décadas de 1970 e 1980, em que foram verificados sistemáticos conflitos armados na região.

Nesse sentido, pode-se questionar o comprometimento brasileiro em solucionar a problemática dos refugiados no decorrer destas duas décadas. Isso porque o país, que havia optado pelo dispositivo da Convenção que reconhecia como refugiados apenas as pessoas de origem européia (a chamada "reserva geográfica"), poderia, mediante comunicação ao Secretário-Geral da ONU, ter adotado o outro dispositivo que abarcava pessoas provenientes de qualquer lugar do mundo. Pode-se afirmar que a razão pela qual o Brasil náo procedeu dessa forma se pauta no fato de que o país também era governado por um regime ditatorial e, diante disso, acolher pessoas que abandonavam seus países em decorrência de conflitos armados ocasionados por motivos políticos não deveria constituir uma prioridade para o governo.

É a partir da redemocratização brasileira que a problemática dos refugiados reassume o caráter de uma questão importante para o país. Significativas mudanças ocorreram desde então, marcando o comprometimento do Brasil com esta problemática. Dentre elas, pode-se destacar o fim da reserva geográfica no início dos anos 1990, quando o país passa a receber refugiados provenientes de todos os cantos do mundo, e aplicação da definição ampliada de refugiado aos angolanos aqui acolhidos.

Portanto, pode-se concluir que, durante o período compreendido entre o pós-guerra e os dias atuais, tanto o Brasil como os demais países da América Latina procuraram se inserir no contexto de preocupação internacional com a problemática dos refugiados e vêm atuando no sentido de solucioná-la. 
Todavia, a ocorrência de conflitos no cenário internacional atual revela que esta problemática é muito difícil de ser resolvida e que requer ainda grandes desafios da comunidade internacional a serem vencidos.

\section{Referências Bibligráficas}

ACNUR. A situação dos refugiados no mundo: cinqüenta anos de ação humanitária. Almada: A Triunfadora Artes Gráficas, 2000, 345 p.

. Actualidad en Argentina, Bolivia, Brasil, Chile, Paraguay y Uruguay. jul. 2002. Disponível em: http://www.acnur.org. Acesso em: 19 de abril de 2005.

. Background on the executive committee. jul. 2001. Disponível em: http:// www.unhcr.ch. Acesso em: 20 de abril de 2005.

. Convenção relativa ao estatuto dos refugiados. Manual de Procedimentose Critérios a Aplicar para Determinar o Estatuto de Refugiado. Lisboa: ACNUR, 1996, p. 60-84.

- Definición ampliada de refugiado en América Latina: incorporación de la Declaración de Cartagena en la legislación de la región. jul. 2004a. Disponível em: http://www.acnur.org. Acesso em: 15 de julho de 2005.

2003 Global Refugee Trends: overview of refugee populations, new arrivals, durable solutions, asylum-seekers and other persons of concern to UNHCR. 15 jun. 2004b. Disponível em: http://www.unhcr.ch. Acesso em: 20 de abril de 2005 .

. 2003 Statistical yearbook. 2004c. Disponível em: http://www.unhcr.ch. Acesso em: 20 de abril de 2005.

. Manual de procedimentos e critérios a aplicar para determinar o Estatuto de Refugiado. Lisboa: ACNUR, 1996, 95 p.

- Protocolo sobre o Estatuto dos Refugiados. Manual de procedimentos e critérios a aplicar para determinar o Estatuto de Refugiado. Lisboa: ACNUR, 1996. p. 85-89.

Refugiados colombianos obtienen una nueva oportunidad en Brasil. 11 mar. 2005. Disponível em: http://www.acnur.org. Acesso em: 19 de abril de 2005. 
20 de junio Día Mundial del Refugiado. 2003.

ADITAL. Refugiados colombianos se adaptam a la vida en Brasil. 21 mar. 2005. Disponível em: http://www.adital.org. Acesso em: 30 de abril de 2005.

ALMEIDA, Guilherme Assis de. Direitos humanos e não-violência. São Paulo: Atlas, 2001, 186 p.

ANDRADE, José Henrique Fischel de. A lei brasileira de proteção aos refugiados. Correiro Braziliense. Brasília, 29 set. 1997a. Caderno Direito \& Justiça.

A proteção internacional dos refugiados no limiar do século XXI. Travessia-Revista do Migrante, p. 39-42, mai-ago. 1996a.

O Brasil e a proteção de refugiados: a discussão tem início no Congresso Nacional. Pensando o Brasil, ano V, n. 16, p. 7-12, set. 1996b.

O refugiado à luz do Direito Internacional e do Direito Brasileiro. Advogado: Desafios e Perspectivas no Contexto das Relaçóes Internacionais, Brasília, p.149-164, 1997b.

- Regional policy approaches and harmonization: a latin american perspective. International Journal of Refugee Law, Oxford, v. 10, p. 389-409, 1998.

ARAÚJO, Nádia de; ALMEIDA, Guilherme Assis de (Coord.). O Direito Internacional dos refugiados: uma perspectiva brasileira. Rio de Janeiro: Renovar, 2001, 445 p.

COMISSÃO JUSTIÇA E PAZ. Direitos Humanos no Brasil: 1992-1993. São Paulo: Loyola, 1994, 87 p.

DECLARAÇÃO de Cartagena. In: ARAÚJO, Nádia de; ALMEIDA, Guilherme Assis de (Coord.). O Direito Internacional dos refugiados: uma perspectiva brasileira. Rio de Janeiro: Renovar, 2001, p. 421-430.

DIÁRIO DE S. PAULO. Histórias de guerra e tragédias são freqüentes. 2004. Disponível em: http://www.diariosp.com.br. Acesso em: 15 de maio de 2005.

ISTO É. A saga dos sem-pátria. 15 out. 1997. Disponível em: http://www.zaz. com.br/istoe. Acesso em: 25 de maio de 2005.

O ESTADO DE SÃO PAULO. Refugiados. 2004. Disponível em: http://estadao. com.br. Acesso em: 25 de abril de 2005.

PIOVESAN, Flávia. Direitos Humanos e o Direito Constitucional Internacional. 6. ed. São Paulo: Max Limonad, 2004, 487 p. 
ZARJEVSKI, Yéfime. A future preserved: international assistance to refugees. Oxford: Pergamon Press, 1987, 300 p.

Tabela 1 - Refugiados acolhidos em Sáo Paulo em 2003

\begin{tabular}{|c|c|}
\hline Países de Origem & Refugiados \\
\hline Angola & 368 \\
\hline Libéria & 139 \\
\hline Serra Leoa & 129 \\
\hline Cuba & 73 \\
\hline Iraque & 54 \\
\hline Rep. Democrática do Congo & 53 \\
\hline Peru & 36 \\
\hline Colômbia & 30 \\
\hline Sérvia & 25 \\
\hline Nigéria & 21 \\
\hline Sudão & 20 \\
\hline Croácia & 18 \\
\hline Irã & 18 \\
\hline Burundi & 15 \\
\hline Líbano & 14 \\
\hline Ruanda & 12 \\
\hline Iugoslávia & 11 \\
\hline Bósnia & 10 \\
\hline Argentina & 7 \\
\hline Somália & 6 \\
\hline Argélia & 5 \\
\hline Macedônia & 5 \\
\hline Marrocos & 5 \\
\hline Síria & 5 \\
\hline Camaróes & 4 \\
\hline Egito & 4 \\
\hline Etiópia & 4 \\
\hline Tanzânia & 4 \\
\hline Armênia & 3 \\
\hline Faixa de Gaza & 3 \\
\hline Federação Russa & 3 \\
\hline Guiné Bissau & 3 \\
\hline Paraguai & 3 \\
\hline Burkina Faso & 2 \\
\hline Congo-Braziville & 2 \\
\hline El Salvador & 2 \\
\hline
\end{tabular}




\begin{tabular}{|c|c|}
\hline Países de Origem & Refugiados \\
\hline Geórgia & 2 \\
\hline Montenegro & 2 \\
\hline Sri Lanka & 2 \\
\hline Vietnã & 2 \\
\hline Afeganistão & 1 \\
\hline África do Sul & 1 \\
\hline Gana & 1 \\
\hline Haiti & 1 \\
\hline Mauritânia & 1 \\
\hline Moçambique & 1 \\
\hline TOTAL & $\mathbf{1 . 1 3 0}$ \\
\hline
\end{tabular}

FONTE: Cáritas Arquidiocesana de São Paulo

Tabela 2 - Refugiados acolhidos por países da América Latina em 2003

\begin{tabular}{|c|c|}
\hline Países de acolhida & Refugiados \\
\hline Argentina & 2.642 \\
\hline Belize & 861 \\
\hline Bolívia & 527 \\
\hline Brasil & 3.193 \\
\hline Chile & 466 \\
\hline Colômbia & 186 \\
\hline Costa Rica & 13.508 \\
\hline Cuba & 836 \\
\hline Ecuador & 6.381 \\
\hline El Salvador & 246 \\
\hline Guatemala & 715 \\
\hline Haití & - \\
\hline Honduras & 23 \\
\hline México & 6.075 \\
\hline Nicarágua & 300 \\
\hline Panamá & 1.445 \\
\hline Paraguai & 28 \\
\hline Peru & 718 \\
\hline Uruguai & 91 \\
\hline Venezuela & 58 \\
\hline & \\
\hline & \\
\hline & \\
\hline
\end{tabular}

FONTE: 2003 Global Refugee Trends: overview of refugee populations, new arrivals, durable solutions, asylum-seekers and other persons of concern to UNHCR, p. 9 
Tabela 3 - Refugiados provenientes de países da América Latina em 2003

\begin{tabular}{|c|c|}
\hline Países de origem & Refugiados \\
\hline Argentina & 784 \\
\hline Belize & 10 \\
\hline Bolívia & 264 \\
\hline Brasil & 378 \\
\hline Chile & 1.555 \\
\hline Colombia & 37.981 \\
\hline Costa Rica & 92 \\
\hline Cuba & 16.103 \\
\hline Ecuador & 731 \\
\hline El Salvador & 5.658 \\
\hline Guatemala & 6.696 \\
\hline Haití & 7.549 \\
\hline Honduras & 604 \\
\hline México & 1.652 \\
\hline Nicarágua & 3.983 \\
\hline Panamá & 30 \\
\hline Paraguai & 32 \\
\hline Peru & 5.582 \\
\hline Uruguai & 57 \\
\hline Venezuela & 598 \\
\hline & \\
\hline
\end{tabular}

FONTE: 2003 Global Refugee Trends: overview of refugee populations, new arrivals, durable solutions, asylum-seekers and other persons of concern to UNHCR, p. 21-22 